\title{
Let the River Flow: Fighting a Dam in Communist Hungary
}

\section{David A.J. Reynolds}

\begin{abstract}
Faced with communist Czechoslovakia and Hungary's 1977 scheme to construct a diversion canal and hydroelectric dam system on the Danube, a movement gradually arose in Hungary to fight the plan. This national dissident campaign, which started with discussion groups and technical articles, not only brought in an extraordinary cross-section of opinion and background - united around the preservation of natural heritage - but played a key part in the rebirth of a lively civic society within a long repressed political and intellectual culture. The story of this movement's arguments, strategies, and ultimate success is both a key story in the decay and collapse of communist rule in Hungary, and a case study in how a non-western European/American approach to the politics of preservation can rally support and achieve consensus.
\end{abstract}

Keywords: Hungarian civic society, Danube, hydro-electric dams, dissent in communist Hungary, preservation, Czechoslovak-Hungarian relations

Biography: David A.J. Reynolds is a British writer, teacher, and editor who has lived and taught in Hungary, the Czech Republic, and the United States, where he gained a Master's degree in history from West Chester University. A frequent contributor to Hungarian Review and The Technoskeptic, he is the author of Revising History in Communist Europe: Constructing Counter-Revolution in 1956 and 1968 (Anthem Press, 2020).

david.reynolds@alej.cz.

What does a river mean to the people who live by it, with it and on it? A river can be both continuity with the ages gone and constant regeneration: water that is ever new grooves millennia-old channels into the landscape and culture of nations. "The Danube, which is past, present, future," wrote the great Hungarian poet Attila József, musing on the connection between the ancient and the current of his country, "entwines its waves in tender friendly clasps." As he begins the poem, A Dunánál ['By the Danube'], gazing at the river, he is seized by the connection not only between the centuries that had passed by the river, but between the Danube and himself: "As if my heart had been its very source" (József 2013: 52-55). What happens, then, when the hammer blows of modern technology threaten these links? There have been responses that will not easily sit within Western European and American ideas of environmentalism. It was there, in communist Hungary, where this pan-European river flows and bends as the Upper Danube becomes the Middle Danube that a moment of striking resistance to river despoliation occurred.

"An atmosphere of prehistoric survival hung in the air," Patrick Leigh Fermor remembers of the Danubian island, Ada Kaleh. Fermor's legendary trilogy recounts his 1930s ramble from the Hook of Holland to Constantinople, and, by the end of the second book, Between the Woods and the Water, he has reached the Iron Gates gorge, where the Danube

(cc) BY

ULLS D-Serle 
roared between Romania and Serbia. Sculling out from the town of Orsova, Fermor landed in minutes within the last Ottoman enclave of the region, a place that transported the traveler centuries back. Thirty-five years later, the island scene that spread mysteriously before Fermor was gone, drowned along with old Orsova and many other villages and hamlets, under the massive reservoir created by a new hydroelectric dam (Fermor 1986: 243-53).

The dam at the Iron Gates stands as a fitting symbol of the modern ruination of the Danube, and not only because of its gargantuan size; in addition to taming and smothering one of the river's most idiosyncratic stretches, the dam also condemned its quintessential inhabitant, the sturgeon, to extinction. Long before the great kingdoms of Europe emerged and gathered around the Danube, the sturgeon had spawned in the Szigetköz and Csallóköz regions of the upper Danube, swum downriver to the Black Sea and then returned to the same heart of the continent to repeat the process. While the massive creatures came to be heavily fished as they plied their way back upstream, they remained ubiquitous on the Danube until humankind decided that a river was nothing more than a source of electricity sitting mutely beneath his abstract computations. The giant Serbian-Romanian dam blocked the sturgeon's ancient life-path, throttling its population.

It is on the upper Danube that the heavy hand of dams has come down the hardest. Between the river's Swabian source and what is now the Slovak capital, Bratislava (formally Pozsony or Pressburg), fifty-nine dams crowd the Danube's burdened course, obstructing its life, on average, every sixteen kilometers (ten miles). "Up to the middle of the nineteenth century, the Danube was a free-flowing wild river in most parts," describes BBC journalist and author of The Danube: A Journey Upriver from the Black Sea to the Black Forest, Nick Thorpe. The mighty and mysterious river "was in a state of dynamic balance, in which this system could regulate itself" (Thorpe 2012). Even as giant dams wrought their customary devastation at both ends of the Danube, there remained pockets of mostly unspoiled river between.

One such unspoiled area could be found downriver of Bratislava, first in the fabulous inland delta of the Csallóköz (Žitný ostrov in Slovak) and Szigetköz, and then into the Danube Bend, where the river turns abruptly south, among forested hills, towards Budapest. "Happy to slip beyond the control of the stern banks," as novelist Algernon Blackwood described the river among the Csallóköz and Szigetköz at the beginning of the twentieth century, "the Danube here wanders about at will among the intricate network of channels intersecting the islands everywhere with broad avenues." As he continues, "the fascination of this singular world of willows, winds, and waters, instantly laid its spell upon us" (Blackwood 2019: 7-8). Yet it was precisely amongst this stretch of varied riparian treasures that the communist regimes of Czechoslovakia and Hungary conspired in 1977 to launch a massive dam project. The nature and consequences of the scheme serve as a fitting representative of similar projects across the world, both past and present. As we will see, the Hungarian campaign that emerged to challenge it also provides us with a unique and greatly needed example of a society rising up against the destruction of its natural heritage.

\section{The Postwar Momentum Toward the Dam}

In the immediate postwar years, the United States and the Soviet Union both redoubled their efforts in producing the gigantic technological feats that became monuments to their hubris. For the Central and Eastern European states that fell under the latter's sway, this meant being forced to embark on a course of rapid industrial development that was often heedless of local 
Reynolds, David A.J. "Let the River Flow: Fighting a Dam in Communist Hungary." Hungarian Cultural Studies. eJournal of the American Hungarian Educators Association, Volume 13 (2020) DOI: 10.5195/ahea.2020.391

conditions. Stalin, a man who renamed himself after steel, had already set the Soviet Union on this course in an attempt to transform a rural empire into the world's model of heavy industry, no matter the cost for the people and their land. The late 1940s brought new urgency; the times were encapsulated in 1948 by Stalin's so-called "Great Plan for the Transformation of Nature" (Josephson 2016: 1-2). In 1951, the leader of communist Czechoslovakia, Klement Gottwald published For the Happiness of the People: The Transformation of Nature in the Stalinist Era, the cover of which featured Stalin redrawing Soviet rivers with his fingers (Josephson 2016: 20).

It was in this context and spirit of presumption that the idea of a Czechoslovak-Hungarian dam system on the Danube was seriously mooted. In a 1950 appearance before the Magyar Tudományos Akadémia (MTA) ['Hungarian Academy of Sciences'], the prominent water engineer Emil Mosonyi urged emulation of the Soviet example through such a project. "The Soviet Union's recently published gigantic plans sharply illuminate the extraordinary importance of hydropower management." Furthermore, Mosonyi added, "the news about those monumental technical creations should also influence us. Let us stand for a while in front of the map of Hungary in a festive mood with the desire to construct" (Vargha 2015). Although the building of a hydroelectric dam at Tiszalök on the Tisza River in north-eastern Hungary was already underway, the Danube idea was of a magnitude commensurate with the pretentions of the age. In their assessment of early 1950s Party propaganda in Hungary, Zsuzsanna Borvendég and Mária Palasik conclude that the official opinion "shows how the Communist thinking not only ignored the idea of protecting nature and pursuing sustainable development, but was outright proud of forcefully interfering with its environment and transforming living nature to its own image" (Borvendég and Palasik 2016: 194). Communist regimes were not outliers in this regard, but rather extreme examples of a common modern approach (Harden 2012: 25-26; Josephson 2002: 17; Reynolds 2019; Fradkin 1996: 25-26).

The Stalingrad hydro-electric plant on the Volga was a stunning, heroic monument, one akin to the greatest works of art, gushed the Hungarian Communist Party daily, Népszabadság ['The People's Freedom'] in connection to the model Soviet project after the first dam agreement was made between Czechoslovakia and Hungary in 1958 (Kien [Vargha] 1984). Signed by Hungarian Prime Minister Ferenc Münnich in Prague, this deal launched years of planning, hidden from public view. When a further agreement was reached between the two regimes, in April 1963, the scope and focus of the project was taking shape, including a landmark canal on Czechoslovak territory into which a large portion of the Danube would be diverted. Eager to press ahead with the dam, Mosonyi had a decade before promised Czechoslovak colleagues that he could obtain Hungarian governmental permission for this concept within a fortnight, but had been rebuffed at the time by one of the pre-1956 regime's leading Stalinists, Ernő Gerö (Vargha 2015). Now the diversion of the Danube, at a location where the river formed an international border between the dam partners, garnered a place in the plans that would not be relinquished.

This strange surrender of the Danube itself by the Hungarian state reminds us of another powerful force leading toward the dam. From the advent of large, hydroelectric dams until the present, these projects have attracted leaders seeking to boost both personal and collective egos, thereby asserting the independence and confidence of new nation-states. Trumpeted as virile seizures of initiative, giant dams are invariably cast as expressions of national strength and lauded - even as they swallow ever-increasing funds for little benefit - as monuments to modernist success (Hiltzik 2010; D’Souza 2002). Yet who would get to play that card in this joint project? To understand how this scheme was both served and driven by a one-sided 
conception of national interest, we have to appreciate the ways in which the Danube had become a border between Hungary and Czechoslovakia in the first place.

The First World War came to a close with the economic and social disintegration of the Central Powers, shattering three empires (Habsburg, German, and Ottoman, with a fourth, the Russian Empire, having already imploded mid-war). Both the Habsburg Empire, which included Bohemia and Moravia, and the associated, Habsburg-ruled Kingdom of Hungary - which for 900 years included the Felvidék ['Uplands'] now known as Slovakia—were defeated and helpless. It was an opportunity for the many ethno-national groups that had been advocating for greater autonomy to seize power. The grandiose concept of 'national self-determination', which supposedly guided the drawing of new European boundaries, faintly masked the diplomatic jockeying behind the scenes (Irmanová 2009; Kien [Vargha] 1984; Nicolson 2009). The question was, who could get what they wanted from the victorious allies.

Having long comprised a venerable kingdom, Bohemia and Moravia, also referred to as the Czech lands, had an unimpeachable case for post-war statehood. A more complicated issue was the successful demand to include large areas within the Felvidék where Slovaks were numerous in the new state (Slovaks being related fellow-Slavs to the Czech people). The argument was that, since Slovaks were in the majority throughout the Felvidék as a whole, this region ought to be entirely within the new ethnically-defined republic centered far away in Prague. However, in the south of the Felvidék, including on the north bank of the Danube, Hungarians and ethnic Germans outnumbered Slovaks. For example, a study of the French Foreign Ministry in November 1918 found that the area in which Slovaks predominated neither reached the Danube, nor included Pozsony (now Bratislava) (Kien [Vargha] 1984). Furthermore, according to the 1910 census, the population of the Csallóköz section of Komárom County, north of the Danube, was 99.8\% Hungarian (“1910. Évi Népszámlálás” 1912: 20-21). ${ }^{1}$

As the Slovak nationalist politician Vavro Šrobár relevantly commented, "It will belong to those who will lay a hand on it first" (Irmanová 2009). Therefore, while the new Czechoslovak Army occupied territory down to the Danube with the crucial encouragement of France, the Czechoslovak delegation at the Paris peace conference insisted that its new state extend to the great river: a "frontier on the Danube is, for the Czecho-Slovak Republic, of the most vital importance. It admits of no concession, nor yet of being discussed with the Magyars [Hungarians]" (Wandycz 1962: 64). They got what they wanted, even including - around the new Slovak capital Bratislava - areas south of the Danube.

For Slovaks in particular, and the new Czechoslovak state in general, access to the Danube secured a valuable economic and geo-political position. As the Czechoslovak delegation in Paris received most of their demands, the promise of hydroelectric power was already casting its spell. In this, France was also an example. With World War I once more extending its

\footnotetext{
${ }^{1}$ The 1910 census in question was carried out by the Kingdom of Hungary. Unlike the Austrian lands, which calculated ethnic demographics according to respondents" "language of daily use," the Hungarian census did so according to respondents" "mother tongue." The definition used for this concept in the census guidelines was the language "to which one confesses as one's own and with which one best and most gladly speaks." This guidance was accompanied by the clarification: "Although mother tongue is identical with the language which everyone learned in their childhood in the majority of cases, usually from their mother, it can nevertheless happen that a child has another mother tongue than the mother ...”' (Klein-Pejšová 2015: 52-53).
} 
territory eastwards to the Rhine, France's government pressed home their advantage by reviving and extending an old plan (the Grand Alsace Canal) to divert the Rhine into an artificial canal on the left bank-now on French land-over a one-hundred and twenty kilometer stretch from Basel to Strasbourg, with hydro-electric plants along its course. The final text of the Versailles Treaty gave France "the right to take water from the Rhine to feed navigation and irrigation canals (constructed or to be constructed) or for any other purpose," as well as, "the exclusive right to the power derived from works of regulation on the river," and, "the right to carry out in this part of the river all works of regulation (weirs or other works) which she may consider necessary for the production of power" (Article 358). In case there was any doubt, the article added that Germany "binds herself not to undertake or to allow the construction of any lateral canal or any derivation on the right bank of the river opposite the French frontiers."

Seeking advantages similar to those secured by France on the German side of the Rhine, the Czechoslovak delegation in Paris proposed that it be given both exclusive rights to develop hydroelectric facilities on the Danube as well as the freedom to make alterations on the Hungarian and Austrian sides of the river for this purpose. Since it was already a major concession that Czechoslovakia extended to the Danube, this was a power grab too far. In the 1920 Treaty of Trianon, which completed the work of postwar conferences and finalized the dismemberment of Hungary, Czechoslovakia was given the right (if permitted by the International Danube Commission) to "undertake maintenance, improvement, weir, or other works" not only on the river, but also "on the opposite bank, and also on the part of the bed which is outside their territory" (Article 290). In fact, in 1924, Emil Zimmler, a hydraulic engineer heading the Water Management Department of the Czechoslovak Ministry of Public Works ['Ministerstvo veřejných praci'], broadly interpreted Article 290 as granting his new state exclusive rights to use the Danube for power generation and promised that it would fully avail itself of this supposed prerogative (Kien [Vargha] 1984).

Therefore, in the creation and assertion of the new Czechoslovak state, consolidating access to the Danube through hydroelectric utilization became a non-negotiable vision of national strength. In the late 1940s, the advent of communism in both countries applied the pressure and motivation to secure such projects. Meanwhile Hungary, once more on the losing side in the Second World War and occupied by Soviet troops, entered the postwar world constrained (to a unique degree within communist Europe) from advancing nation-based arguments or advocating for its millions of co-nationals in the surrounding states. Thus, the natural beauty of Csallóköz, which was now in Czechoslovakia but still mostly populated by Hungarians, became expendable as the dam plans crystalized. In both 1959 and 1962, Hungarian water engineers made study trips to the Grand Alsace Canal, the French river-capturing precedent secured by the Versailles Treaty (Vargha 2015).

Despite being used as a model for the new Danube dam project, the Grand Alsace Canal had sunk into a decades-long morass of negotiation and controversy, resulting in only fifty-one kilometers of its intended one-hundred and twenty being built. Superpower influence had also been applied here in the 1950s, with two hydroelectric dams built on the shortened canal with Marshall Plan funds. Yet there could be little doubt, especially by the 1960s, that a large diversion canal, as it denuded the original riverbed, had disastrous effects on the groundwater 
and everything, including agriculture, which fed upon it. $^{2}$ As would become increasingly clear in the years to come, the Danube planners had little to no interest in such details: their faith in and fixation upon the grand re-engineering of nature left no room for contradiction.

\section{The 1977 Dam Treaty between Hungary and Czechoslovakia}

Escaping from Bratislava in a south-easterly direction and running between the Csallóköz and Szigetköz, the Danube dashed wildly amongst numerous channels and islands. Twenty-five kilometers into this dance, the river reached, on the southern bank, the Hungarian town of Dunakiliti. It was here - according to the treaty that Hungary and Czechoslovakia formalized on September 16, 1977-that the river's course would be arrested by a giant dam. This new dam would, firstly, hold part of the Danube's flow in a reservoir that widened almost back to Bratislava; unlike most hydroelectric dam projects, this was not the means of power generation. At this stage of the Danube, the river hardly drops in elevation at all, as it passes through flat wetland. The Dunakiliti dam was therefore primarily designed to divert the Danube north of its riverbed onto Czechoslovak territory and into a parallel canal of concrete and asphalt, running for thirty kilometers. Along the canal, made to decline more steeply than the riverbed, a massive power plant was to be built at Gabčíkovo (known as Bös in Hungarian). Once the waters were pushed through the eight turbines of Gabčikovo, they would rejoin the Danube riverbed north of the city of Györ (Erskine 1994: 56-57; Kien [Vargha] 1984). But this was not the end of it.

After the vicinity of Györ, the Danube runs due east for over a hundred kilometers before reaching the Danube Bend. Having disrupted the flow, level and constancy of the river with the dam and diversion canal, the 1977 treaty included tactics for addressing the consequences by compounding them, as is typical in such projects. Firstly, the river would be canalizedartificially deepening the riverbed - both before and after the bend. (The deleterious effects of this process are well documented, e.g., Munoz 2018; Klein and Zellmer 2014.) Just before the bend, the agreement stipulated a second dam at Nagymaros, by the ancient fortress of Visegrád, to complete the post-canal 'stabilization' of the river and add further power generation. Particularly since the loss of two-thirds of its territory after World War One, Hungary contained no spot more beautiful than this, one of those precious gifts that the Duna, as Hungarians know it, had granted them. In the midst of it, there were to be locks, a dam, and a power plant.

The first stirrings of opposition in Hungary to the dam project were based on financial considerations from within the regime. Grandiose pretentions aside, there is scant case for a hydro-electric dam unless its enormous costs are more than returned in efficiently and sustainably produced energy. Yet it takes years, far beyond a project's point of no return, to prove that a giant dam has failed this most basic test. When researchers at Oxford University studied two-hundred and forty-five large dams constructed between 1937 and 2004, they reported that "the actual construction costs of large dams are too high to yield a positive return"

\footnotetext{
2 Already in April 1953, the Hungarian Politburo member and Deputy Prime Minister Ernő Gerő chaired a meeting - the minutes were published in samizdat journal Beszélö in 1985-at which it was discussed that the water table was estimated to lower by four to five meters as a result of the diversion of the Danube. The Hungarian engineers that made the aforementioned 1959 trip to the Grand Alsace Canal also reported back that it had not been completed due to the drop in the water table that the first section had caused (Vargha 2015).
} 
Reynolds, David A.J. "Let the River Flow: Fighting a Dam in Communist Hungary." Hungarian Cultural Studies. eJournal of the American Hungarian Educators Association, Volume 13 (2020) DOI: 10.5195/ahea.2020.391

(Scudder 2019: 250). Even if the Hungarian government assumed that its dam project would one day pay off, a large amount of investment capital needed to be secured, despite the shared costs.

By the late 1970s, the days were gone in which the Soviet Union routinely leveraged massive infrastructural projects across Central and Eastern Europe; by the time it was launched, the long gestation period of the Danube project had made it somewhat of an anachronism. Indeed, Hungary was still burdened by the impractical and abstract way in which so-called development had been directed and implemented in the 1950s (Tőkés 1996: 90-91).

Furthermore, the most immediate motivation for new power generation - the steep increase in the price of Soviet energy imports since 1975-was also a sign of a more adversarial economic relationship between the Soviet Union and its beholden satellites (Zloch-Christy 1987: 86). Hungary was now in the unenviable position (which would only deepen in the years to come) of being both desperate for new foreign investment and desperately indebted to foreign sources. Nevertheless, Hungary had signed the dam treaty with Czechoslovakia based on assurances it had previously received of a Soviet loan to cover part of the costs. In March 1979, the Soviets let it be known that equipment, but not finance would be forthcoming. Therefore, in 1980, the Hungarian government temporarily suspended work on the Gabčíkovo-Nagymaros system; in the following year, progress was severely restrained by a lack of funds.

While a shortage of capital was hampering construction on the Hungarian side, the project was receiving sustained scrutiny from scientists, engineers and other relevant experts. As it did so, warnings and alarm bubbled to the surface of professional bodies and government departments. The fiscal crisis served as a stimulant to the expression of legitimate objections that might otherwise have been swallowed. "Of the professional groups," campaigner Judit Vásárhelyi would later recall, "it was the architects and engineers led by technical as well as by moral motives [who took] the lead" (Vásárhelyi 1985). For example, in May 1980 the Magyar Hidrológiai Társaság (MHT) ['Hungarian Hydrological Society'] hosted a conference on the natural consequences of the dam project, at which, according to János Vargha (much more of him soon), the plan was lambasted by biologists and engineers alike (Kien [Vargha] 1984). Communist states prided themselves on technical expertise; non-ideological objections expressed in professional and academic circles were a form of dissent that the regime could not easily dismiss. These were the first cracks.

Critics were boosted by the beginning of co-operation between the concerned and the increasing dissemination of dissent. In this process, a biologist and journalist named János Vargha, who started investigating the issue in 1980, was a catalyst. Although the bare details of the project had appeared in the official press when the original treaty was signed in 1977, nothing was communicated of what it meant for the places involved, while the energetic debate within professional groups remained hidden from the general public. When Vargha was confronted by the fears of riverside villagers in the crosshairs of the dams, he began digging. "The more he dug," recalls MTA biologist Gábor Lövei, "the more it smelled" (Hamilton 1989). In November 1981, Vargha was ready to publish his findings in the periodical, Valóság ['Reality'], under the title Egyre távolabb a jótól ['Ever Farther from Good'].

Mining many studies, some dating back to the early 1950s, Vargha's report presented established evidence regarding how the upriver dam and the lateral canal would devastatingly reduce groundwater in the Szigetköz, pollute the enormous sub-Danubian aquifer on which the region relied for drinking water and increase flood risk in the heightened waters behind the dam. Perhaps most devastatingly, Vargha showed that in spite of long-held reservations about the 
possibility of this dam project viably producing power, energy production remained its justification, to the extent that modifications which would increase the damage and risk to land and people - while marginally increasing production - were approved. Transfixed by the unreachable, they seemed content to destroy what was in their hands.

Other negative assessments continued to accumulate, while the Hungarian government embraced neither the criticism nor the project it had committed to help build. In June 1983, the Országos Környezet- és Természetvédelmi Tanács ['National Environment and Nature Conservation Council'] concluded that the Gabčíkovo-Nagymaros plan did not address "ecological effects and expected consequences," while the MTA delivered a report to the government recommending that the scheme be cancelled, or, if that were not possible, modified (Haraszti 1986). ${ }^{3}$ Nevertheless, Hungary seemed to be "dammed" whether they did or did not. Between the above reports, in July 1983, the two countries signed an update to the treaty, acknowledging that the project would not be completed until 1994, four years' later than originally planned. Since the Czechoslovak side had mostly continued work while the Hungarians prevaricated, the new agreement also gave the former a far greater share of the power produced in the opening years of the Gabčíkovo plant, which was due to be finished first.

Official ambivalence meant that the Party-state no longer trumpeted the project, but also did not quite know what to do with the small group of engaged and informed citizens who were clear about its dangers. In December 1983, Vargha published his criticisms in the prestigious weekly news magazine, Heti Világgazdaság ['Weekly World Economy'], and the following month, the deputy-head of the government's water authority (OVH: Országos Vizzigyi Hivatal ['National Office of Water Affairs']), Dr. László Nagy, agreed to debate Vargha. It was an incredible opportunity, since the OVH had been the project's consistent and inflexible booster. The discussion was due to take place at the Rakpart Klub ['Quay Club'], which had been founded in 1982 as a forum of young intellectuals by Mihály Horváth, who, as his eulogy later recalled, "wanted to create an island of democratic expression in a sea of anti-democracy" ("In Memoriam Horváth Mihály" 1988. Translation by author). Rakpart Klub debates quickly became, through word of mouth, popular venues for asking bold questions, seeking information and poking the taboos of a totalitarian status quo that rested far more on tactful acquiescence than overt coercion.

At the eleventh hour, Nagy of the OVH declined to attend the debate and the Rakpart $K l u b$ was warned not to hold the event. This was a mistake, clearly demonstrating that the regime could not make a reasonable case for the project before a group that was willing and eager to understand it. The Rakpart Klub went ahead with the evening; instead of a debate, Vargha was able to present his case unchallenged. After listening to his arguments and evidence, "a group of students and intellectuals: biologists, architects, artists, historians, lawyers, sociologists and teachers," as one of their number, Vásárhelyi, describes it, "initiated the foundation of an association for the protection of the Danube" (Vásárhelyi 1985). While applying to the authorities for registration as an organization, the group sought to gather people and spread the word. "We had the belief that if the truth was released and people were informed about the project," Vargha later commented, "it would be enough to stop it" (Hamilton 1989).

\footnotetext{
${ }^{3}$ Text from Haraszti (1986) translated by author.
} 
In February, Vargha published a new piece, this time under a pseudonym in the opposition samizdat journal, Beszélö ['Speaker']. Tough and wide-ranging, Vargha's article covered all the usual objections to the dam project, from the despoliation of natural treasures to the contamination of water supplies to the practical uselessness of the goal. Significantly, Vargha also meticulously made the case that, in its roots and effects, the dam scheme was a power-grab specifically disadvantaging Hungary, as his piece's title, A Nagy Szlovák Csatorna ['The Great Slovak Canal'], suggested. This was a bold move, facing a regime that was increasingly vulnerable and sensitive to the charge that it had abandoned the national interest and failed to lift a finger for Hungarians being persecuted in Romania (Kürti 2001: 129, 157). Vargha's multidisciplinary approach was characteristic of what was emerging. The campaign against the Danube dams not only pulled together a broad array of causes and people, but, as it did so, matched and furthered a stirring of principled dissent. This would not be a movement that could easily or accurately be pigeon-holed, either politically or ideologically.

After the new group organized the first public debate about the dams in March 1984, at the Budapesti Müszaki Egyetem ['Technical University of Budapest'], similar events followed around the country. Meanwhile, signatures were collected for a petition urging the government to reconsider. When the first petition was delivered to Parliament at the end of 1984, there were 6,068 signatories, a modest but significant beginning in a society which had long been accustomed to leaving politics and policy to the Party-state in exchange for a consumer-driven economy and a relative lack of coercion. The group was denied registration in September, and so informally coalesced as the Duna Kör ['Danube Circle'], launching its own samizdat publication, Duna Kör Hírei ['Danube Circle News']. "The rationale behind the petition became increasingly known, and satisfied the huge demand for information," Vásárhelyi remembers. "Now, professional debates gained wider publicity: articles, lectures, and panel fora followed each other, and new underground channels were used to make the public understand the irreversibility of certain processes" (Vásárhelyi 2014: 129-30). From this point, the Duna Kör would be a major source of opposition to the dams, while blending and co-operating with many aligned and like-minded groups. The hydro-electric project was, in other words, playing a key role in awakening a new flowering of civil society and independent action in a one-party state.

\section{New Urgency and Opportunity for the Danube Movement}

At the heart of the nascent Danube movement was a rather simple proposition: if enough people within and without the regime understood the nature and consequences of the project, it could not survive. It therefore served as a shock, but ultimately a stimulant, when the reverse seemed to happen. Despite continuing reservations, the government publicly recommitted itself to the dams on August 15, 1985. Furthermore, with the blessings of an OVH report into environmental impact — in which the fox was declaring the henhouse safe-no significant alterations were made to the plan. Overriding diverse and persistent advice from state, academic, and professional partners, the regime added insult to injury by simultaneously launching a new public relations campaign to change the perception of the project, with all press stories on it to be reviewed before publication. As dissident Miklós Haraszti remembers, "an avalanche of propaganda articles was launched in unabashed praise" (Haraszti 1990).

In the end, the new commitment of the state to the project intensified the Danube movement for two main reasons. Firstly, there remained little doubt that the GabčíkovoNagymaros problem was also in part a systemic one. The way and the rationale by which societal 
decisions were made and approved did not mitigate, but rather enabled mistakes such as the dam project. In the light of that unavoidable sentiment, it was also harder to isolate the Danube cause - as if nature preservation were not a holistic matter-from other clubs and groups that sought reform. Anyone with an interest in revising, or even changing, the regime had an interest in this dam debacle, and vice versa. Secondly, the government's decision to dig in its heels made it clear that neither information nor dissent would be enough, if they did not generate pressure. Tactics would need to reflect this reality. The need for pressure was also aided, at this very time, by the increasing international exposure of the Danube movement; at the moment when the regime decided to sweep dam dissent under the carpet, it become harder to do so.

At the end of 1985, it was reported that Austrian companies would help finance the project, with their investment to be repaid through twenty years of electricity supply. It was a strange moment because, although it obviously contradicted the central Hungarian justification for the project (the supposed supply of cheap energy to Hungary), it also removed a major excuse for delaying Hungary's work on it: the lack of available capital. Deepening the absurdity of the project had made it more likely. Yet it also took the issue beyond the confines of the Communist bloc and into Austria, where the protection of nature was already an established and influential area of political life (Lauber 1997). In fact, this vibrancy was precisely why Austria wanted to be involved in the Czechoslovak-Hungarian plans. In 1983, the Austrian government had granted approval for the construction of a large hydro-electric dam at Hainburg, just upriver and across the border from Bratislava, on protected wetland, which would inundate forestland with the resulting reservoir. When workers started clearing the area in December 1984, thousands of protesters occupied the forest to prevent the destruction. As police brutally attacked the non-violent campaigners, public opinion turned sharply against the plan, leading to its cancellation (Mauerhofer 2016: 248). Now the Austrian authorities were seeking to make up for the lost energy supply by exporting the natural devastation eastwards. As they did so, Hungarian campaigners gained a freshly emboldened ally and new platform.

A few weeks after the Austrian partnership on the dam project was announced, the Duna Kör held its first public press conference, on January 16, 1986, at the Zöldfa ['Green Tree'] restaurant in Buda, with Austrian and German colleagues in attendance. "We, German, Austrian, and Hungarian environmentalists protest against the ambition of the Hungarian, Czechoslovak, and Austrian governments," declared the joint statement, "to turn the section of the Danube from Hainburg to Nagymaros into a power-generation canal, endangering the twisting river's wildlife, drinking-water supplies, forests, protected landscapes, and cultural values that need to be defended." Soon after, Haraszti wrote a full-page advertisement, signed by various Hungarians, which appeared in the Austrian daily, Die Presse. "It aimed at reawakening the democratic conscience of the Austrians rather than only at promoting ecological considerations," Haraszti's testifies. "After all, our only hope was that the Austro-Hungarian deal, which was extremely advantageous to Austria, would become politically untenable" (Haraszti 1986).

At this stage, what was needed for the anti-dam movement within Hungary was not necessarily immediate success, but rather the willingness of dam opponents to act in new ways, forcing the party-state to openly oppose what it would prefer to ignore. This brought the illogical and heedless position of the regime into the clear light of day. For example, a Budapest march was planned for February 8 1986, from Batthyány Square, on the Buda side of the Danube opposite the Parliament building, downriver to Margitsziget ['Margaret Island']. When the police forced the Duna Kör to cancel the event, the Austrians (including MPs) and locals who still 
Reynolds, David A.J. "Let the River Flow: Fighting a Dam in Communist Hungary." Hungarian Cultural Studies. eJournal of the American Hungarian Educators Association, Volume 13 (2020) DOI: 10.5195/ahea.2020.391

showed up at Batthyány Square were beaten and arrested by the police. Recently arrived BBC correspondent, Nick Thorpe, attempted to record the scene and was likewise taken into custody (Thorpe 2013; Haraszti 1990). The Danube movement had reached a stage where the regime regarded it as a threat to its authority. While that would make things more difficult in the short term, it gave the cause power and revealed the party-state's vulnerable position as it made itself the enemy of the great river.

\section{The Local, National, and International Face of Preservation}

Rivers are naturally international concerns, and none more so than the Danube, as it runs through and drains the heart of Europe, from Black Forest to Black Sea. Due to this, it is sometimes asserted that only an international perspective can protect rivers. Yet international, national, and, local desires are not mutually exclusive and need not be contradictory. Furthermore, the genuine, lived, and principled knowledge of a river - as opposed to the abstract hubris that has proved so destructive - will be local and national before it is international, and arrive at the latter all the better for it. Will not those who view rivers as treasures to steward, as their ancestors have done before them, be more likely to care both for their long-term health and seek common cause with others, up and downriver, who think alike?

So it was that the Danube movement in Hungary held together its love and concern for its national inheritance - the long relationship of a specific people and the land on which they livewith a reach across borders. Geopolitics tends to ignore both local reality and the perennial; states have and will seek crude and short-term advantages over their neighbors at great cost, and campaigners had good cause to identify such a phenomenon in the Gabčíkovo-Nagymaros plan. Pointing this out, however, does not necessitate accepting the assumptions and logic behind it. Despite the fact that the areas in Czechoslovakia most damaged by the Gabčíkovo dam were mostly ethnically Hungarian, the whole region and the different peoples who shared it would ultimately be denuded and impoverished by this assault on creation. A genuine international perspective would be the combination of organic, local perspectives. Therefore, while their governments' censorship certainly made this more difficult, the Hungarian campaigners also sought to influence opinion north of the Danube. There were also plenty of Czechs and Slovaks who saw through their government's obliviously technological approach. Having rather hypocritically protested the proposed Austrian dam in Hainburg (before it was cancelled) due to the natural damage it would cause in Bohemia and Moravia as well as increase flood-risk in Bratislava, even the Czechoslovak party-state certainly understood the damage a hydro-electric dam could do across borders.

Even in his bold piece, A Nagy Szlovák Csatorna, in which Vargha had emphasized the severe danger the project would impose on his own land, he also made it clear that both nations would suffer major destruction: comparing relative national damage was not constructive, he concluded, since ecology does not recognize national distinctions (Kien [Vargha] 1984). More significantly, in September 1985, the Czechoslovak dissident movement, Charta 77, disseminated a letter from the Duna Kör to the Czechoslovak people in an appeal to common concerns regarding the dam project. "The hysterical industrialization of the 1950s and the continuous plundering of the economy have caused irreversible damage in many regions of Bohemia, Moravia, Slovakia, and Hungary," the letter argued. "The construction of the planned hydro-electric [dam] system at Gabčíkovo-Nagymaros is likely to have irreversible consequences which will affect all the nations living along the Danube.... We appeal to the Czechoslovak 
public to join us in our fight to defend ecological values and the Danube region." The Danube, proclaimed the letter, in Czech, was "our common natural treasure" (Vásárhelyi 2014: 131; "Charta 77 Document: 22/85" 1985; quote translated by the author).

With the Czechoslovak party-state far more enthusiastic than Hungary about the project, it had always been harder for its citizens to raise objections, especially since it was a more repressive regime by this time. Early findings by Czechoslovak researchers predicting that the dams would kill millions of fish and lower the water table had, as also happened south of the Danube, been quickly buried by the government (Erskine 1994: 57). The Slovak campaigner, Jaromír Śíbl, was a bold and vociferous critic. In early 1988, articles outlining the natural consequences of Gabčíkovo-Nagymaros managed to appear in the Czech newspaper, Mladá Fronta ['Young Front'] and the Slovak newspaper, Nové Slovo ['New Word']. As the Czechoslovak progress on constructing the Gabčíkovo part continued to far outstrip Hungarian work, the burgeoning campaign in Hungary held out the only realistic hope of frustrating the plan's realization.

By 1988, the Danube movement was spread across a variety of groups; while each approached the issue in different ways, they collectively marshalled a wide scope of opinion and sentiment. "While the cause of the Danube became a national passion, it also became the first real movement, an archetype of democratic pluralism" explains Haraszti, "as rivals of the Danube Circle within the anti-project movement" also expanded their activity (Haraszti 1990). There was the Kékek ['Blues'], a more radical group who both wrote to every MP and delivered information into the mailboxes of villagers along the Danube. The Duna Barátai ['Friends of the Danube'] was more conciliatory, seeking 'only' the modification of the Gabčíkovo part and the scrapping of Nagymaros. The pithily-named Bajcsy-Zsilinszky Baráti Társaság Környezetvédö Csoportját ['Environmental Protection Group of the Bajcsy-Zsilinszky Society'] came to the fore as an organizer of protest events. Meanwhile, the Nagymaros Bizottság ['Nagymaros Committee'] sought to co-ordinate among the various bodies. A women's group within FIDESZ - then a fledgling youth opposition group, now the party in power since 2010 - even organized an all-female march against the dams (Bozóki).

As Victoria Pope wrote in her 1989 piece, "A Dam on the Danube: The Greening of Hungarian Politics," issues such as the dam demonstrated a "potential to draw in the silent majority," attracting those, "who might otherwise avoid politics. Once involved, these individuals become networks, which develop into groups. They canvass neighborhoods, give lectures and talk to friends." By way of example, Pope relates that "Árpád Fasang, a Hungarian concert pianist, tried organizing in a novel way. He wrote to Protestant ministers at churches near the Danube, urging them to oppose the dam from the pulpit. Many picked up on the suggestion." The poet, academic, and translator Gyula Kodolányi noted at the time that "the dam is a constellation of the most terrible things this system has created," drawing in economic, aesthetic, localist, individualist, and nationalist critics alike (Pope 1989). The question remained: how could all this activity and pressure break through?

\section{8 - The Most Shocking Year}

With the regime seemingly immovable before a tide of opposition to the project, it was fitting that the principle of public consultation and participation became an effective rallying cry. Although the Communist-imposed constitution of 1949 had empowered the state to initiate referendums, the option had never been used. Two weeks after the landmark public press 
conference, in January 1986, 2,665 signatures accompanied a petition calling for a public debate followed by a referendum on the dams (“A bős-nagymarosi vízlépcsőrendszer krónikája" 1989). Authored by the opposition figure Imre Mécs (who had been sentenced to death after the Hungarian uprising of 1956, before a commutation and his release in the 1963 amnesty) the text of the petition declared that "society is entitled to know the toll it must bear, and has the right to determine" whether it will accept this sacrifice and its consequences (Haraszti 1986). The responsibility of making this historic decision, he continued, should not remain with the government alone, but be shared with society. It was a surprise when the petition actually received an official response. As Haraszti describes it, "a decision not to discuss the petition had been made since the issue in question was a technical one," but, by virtue of a reply, "the right to a petition for a plebiscite had been acknowledged" (Haraszti 1990).

Thus, a referendum became the central demand of the dam opponents, which pushed against the regime's weakness on the issue: insisting upon a policy that it could not credibly defend. The dam opposition was challenging the regime's legitimacy on its own terms, and it was doing so as the regime finally begin to show signs of major retreat before a generally emboldened opposition. In May 1988, János Kádár, who had led the country and Party since being installed by the invading Soviets in the autumn of 1956, stepped down. Although police had violently disrupted a protest on the thirtieth anniversary of the execution of Imre Nagy (who led Hungary during the 1956 uprising) on June $16^{\text {th }}$, two weeks later a large demonstration was permitted against Ceauşescu's persecution of Hungarians in Romania. "Hungarian society is showing signs of increased political activity," Haraszti said at the time, and Danube campaigner Pál Dragon would later look back on 1988 as "the most shocking year," even though it came before the regime change of 1989 and 1990 (Vida 2006). At the heart of this vitality was the Danube movement, and on September $12^{\text {th }}$, it showed its strength.

The demonstration was an extraordinary sight, as the broad thoroughfare of BajcsyZsilinszky Street in the heart of Budapest filled with protesters stretching far back into the distance, slowly making their way from Vörösmarty Square to Parliament. An array of signs representing numerous groups, parties, and anti-dam sentiments bobbed over the heads of protesters as their chants filled the air: Népszavazás! Népszavazás! ['Referendum! Referendum!'], they shouted over and again, and "Let the people decide." When they finally arrived at Kossuth Square, the great square before Parliament named after Hungary's revolutionary hero of 1848 , people had to clamber up monuments and onto balconies to catch a view of the speakers. ${ }^{4}$ The last time this square had been filled with protesters - thirty-two years earlier during the uprising — soldiers had unleashed a crossfire of bullets, massacring scores of men and women. Now, as Vásárhelyi remembers, they chanted for "Houses not dams," poking at the regime's unmet promises and pretentions deep into the evening, at which point leaders delivered the latest petition (Vida 2006). Only those who had lived for decades under a blanket

\footnotetext{
${ }^{4}$ Revealing footage of this protest, as well as a great deal of other source material, can be seen in Ádám Csillag's exhaustive documentary film, Dunaszaurusz (1988), which, as of March 2020, is still available to view on YouTube here: https://www.youtube.com/watch?v=bKFQssTZQRA. Many pictures and documents of the protest can also be viewed here: "1988. Szeptember 12.” Állambiztonsági Szolgálatok Történeti Levéltára ['Historical Archives of the State Security Services']: https://www.abtl.hu/szolgaltatasok/nyiltter/virtualis_kiallitas/tuntetesek_1988/1988.09.12.
} 
of silence could understand what it meant to stand shoulder to shoulder in that place with fellow Hungarians and loudly tell the Party-state that it was wrong; to do so and leave in peace.

A month after the crowds had gathered on its doorstep, Parliament debated the dam project for the first time. Furthermore, television viewers were able to watch most of the speeches, including a careful excoriation of the regime's behavior by the distinguished neurobiologist and former President of the MTA, János Szentágothai. By detailing the government's lack of consultation before committing itself to Gabčíkovo-Nagymaros, Szentágothai revealed to the public the MTA's December 1983 recommendation that the government should cancel the scheme, an opinion that had never been published. According to Szentágothai, the whole plan had been built upon faulty ideas, decided upon in secret and then obfuscated before the people. "The reason for our present difficulties is that we discussed such things as the dam in strictest secrecy behind closed doors" (Pope 1989). Although the still mostly loyal and cautious legislature voted to accept the government's position by three-hundred and seventeen votes to nineteen, another hole had been punctured in the dike of the Party-state's credibility, and it would not be this parliament's last word on the dams.

\section{Cancellation of the Dam and Treaty Withdrawal}

Three weeks after the debate in Parliament, thousands returned to the streets of the capital to again protest the dam and launch another petition drive, this time in an impressive torch-lit parade. The result, in February 1989, was the biggest turnout so far: 140,000 participants demanding a referendum. Meanwhile, the state was being gradually separated from the Communist Party structure, a crucial element in the end of one-party rule. In this process, parliament and the government demonstrated their independence, while both began aligning with the public mood regarding the dam plan. In March, parliament determined to return to the issue in May; when it did, the new Prime Minister Miklós Németh declared, "I wake up at 5 a.m. thinking about Nagymaros" (Hamilton 1989). It was not pleasant thoughts which came early to mind. In an extraordinary speech to Parliament on May $10^{\text {th }}$, Németh mirrored the long-held view of dam opponents when he argued that Gabčíkovo-Nagymaros was an example not only of a disastrous decision, but of a bankrupt decision-making process. "Everyone is absolutely right to object to it," he concluded. Within three days, the government suspended work on Nagymaros, a decision which Parliament approved on June $2^{\text {nd }}$.

The days were numbered not only for the Nagymaros dam, but also for the Communist regime, which was slowly dismantled in concept and law. The central moment was the dramatic and spellbinding public reburial of Imre Nagy as a national hero on June $16^{\text {th }}$, an event that fatally undermined the regime's remaining legitimacy. However, the change came not in revolution but through a negotiated settlement that was hammered out at National Roundtable talks from June to September. Meanwhile, an independent committee, named after its chair Dr. Péter Hardi and including János Vargha, had been authorized by Parliament to reassess the project. Its September report confirmed every reservation of the Danube movement while recommending that the Hungarian government permanently cancel the Nagymaros dam and negotiate with the Czechoslovak government to cease work on diverting the Danube upriver. On October $31^{\text {st }}$, when the suspension was due to expire, Parliament voted to approve these recommendations by one-hundred and eighty-six votes to seven (Schwabach 1996; Fitzmaurice 2018). There would be no hydroelectric dam to disfigure the Danube Bend. 
Just as the recommendations of the Hardi Report reminded everyone, GabčíkovoNagymaros was a joint project between Hungary and Czechoslovakia which would require joint action to entirely cancel. This was also made more complicated by the fact that, as the Hungarian government communicated its new course to the Czechoslovak government in November, the communist regime there was imploding in a far more rapid and spectacular way. However, this did not produce a change of heart commensurate with what had occurred in Budapest. As has already been noted, the greater political will to complete the project in Czechoslovakia had been reflected by far greater progress in constructing the lateral canal and Gabčíkovo power plant on Czechoslovak territory. Furthermore, Czechoslovakia was a federal republic which had legally consisted of constituent Czech and Slovak republics since the 1960s. In the wake of the transition to democracy, it became increasingly difficult for either the federal government or the Czech side to placate Slovak demands for still greater autonomy. Although there was little enthusiasm for the dam project among Czechs in government, Slovaks still regarded it as both a matter of national prestige and an essential element of its independent economic infrastructure. With the federal cabinet split along ethnic lines, the Czechoslovak government pressed ahead and completed work in the autumn of 1992, even before the two republics split in January 1993.

Of course, in order to complete the diversion canal and Gabčíkovo part of the scheme unilaterally, the Czechoslovak side also had to modify the plans. It did so by transferring the site of the diversion upriver a few kilometers, from Dunakiliti to Čunovo, where Slovak territory comes to lie on both sides of the river. As had long been planned, here the Danube is now denuded of most of its water for the length of the long artificial canal. The victory of campaigners against the Nagymaros dam therefore came with a sad twin: based on meagre justification, the Csallóköz and Szigetköz were damaged by a concrete impostor.

\section{The Consequences of the Gabčíkovo Canal and Power Plant}

"In a matter of days, the great bed of the Danube, or rather the labyrinth of beds through which it flowed, on both the Hungarian and the Slovak side, dried up," Thorpe reports. "People on both sides of the river are still counting the cost" (Thorpe 2013). As predicted, parts of this vibrant wetland, nourished and sustained by the rhythmic flood patterns of the river, withered. "The Danube lost its function as a 'life pump' that regularly moistened and drained the riparian landscape," explains the environmental consultant, Alexander Zinke. Even with the provision of some mitigating irrigation, the dam and canal "led to a continuous degradation, with many forest areas drying, fisheries decreasing, and rare pioneer habitats and species largely disappearing. Most former purification effects of Danube waters through the filtering process by rich vegetation and soils are largely lost today." Zinke adds that, "as only a very small amount of water from the reservoir runs through the side-arms" (Zinke 2004). Meanwhile, as the Slovak campaigner, Jaromír Š́bl, outlines, the forestland was completely destroyed by the dam reservoir and "all the high quality agricultural land was lost where the above-ground canal and the power plant were built, and the area between the power plant and old Danube river bed" (Šíbl 2013). As always occurs, the dam also ensures that the sediment and gravel needed to sustain life within the river while replenishing its banks and beds downriver, is trapped, degrading the course of the Danube long after Gabčíkovo.

"Our throat will be cut," a Hungarian fisherman told Thorpe shortly before the dam and canal were opened. Indeed, Hungarian villages on both sides of the river have been devastated and isolated. "These villages are slowly dying," Š́bl comments, because "they lost contact with 
the floodplain and with nature." Of course, despite the rhetoric of Czechoslovak and Slovak governments, Slovaks have also been greatly harmed by the effects of this giant project, with the fall in the water table particularly devastating on the north bank. Furthermore, upriver from the canal and reservoir, flood-risk has worsened. While dams are usually sold as solutions to floods, they instead routinely transfer flooding from areas innately suited to absorbing those floods (and dependent upon them) to places which cannot cope with them. "The average water level in Bratislava has increased by about 50 centimeters," Śíbl states. "It doesn't sound [like] much, but in case of the worst floods, this half meter could make a big difference in Bratislava city centre.... So the flood protection of Bratislava has not improved at all as a result of the Gabčíkovo project - just the opposite" (Š́́bl 2013). Extensive river engineering on the upper Danube has replicated this consequence throughout the area; floods will now produce higher waters in places more vulnerable to flood damage, while wetlands struggle next to asphalt (Thorpe 2012). This is what is generally called progress.

\section{The Legacy of the Danube Movement}

That the successful campaign to cancel the intended Nagymaros dam occurred within a totalitarian system certainly makes it remarkable. Yet it would be a great mistake to regard either the dynamics behind the dam plan, or the resulting difficulties for its opponents, as unique to a one-party state. On the contrary, for over fifty years campaigners across the world have seen the same combination of secrecy, misinformation and coercion pressing large dams on people and their land. Everywhere, technological life encroaches, regardless of political philosophy or government system. It is not that these latter distinctions make no difference - they do-but rather that the ways of thinking and living conducive to large hydro-electric dams are broader and deeper than communism or capitalism.

It is equally regrettable when the Danube movement of 1980s Hungary is blandly recounted as an 'environmental movement'. This is to miss what it has to show us, and to turn one of the great, genuinely grassroots campaigns of the last forty years into a generic example of an abstract phenomenon. It is a description that repeats the process by which so-called green groups in Western Europe and America were relegated to a niche on the political and ideological spectrum. The unplanned genius of the Danube movement was the broad power that the collective and deeply-experienced love of native nature has to mobilize and unite disparate sections of a society. Rightly understood and expressed, the preservation of a river is a transcending cause, one that is hard even for powerful interests to extinguish. "The Danube is an extraordinary, real, and symbolic thing for almost everyone," comments Anna Perczel, one of the Danube activists (Vida 2006; quote translated by the author). Only something this tangible can also be this symbolically powerful.

As Haraszti again aptly puts it, this Danube movement "was not born of laymen joining the opposition but rather of the opposition joining the laymen" (Haraszti 1990). In other words, it did not gain its force and direction from politically-active and ideologically-driven intellectuals; they did, however, add their acumen, as men and women from all walks of life came to see these dams on their river as a defining outrage. Professional opinion, academic research, patriotism, civic spirit, principles of stewardship were all aspects that brought these people to face with their rulers in a confrontation which they had not sought. The Danube movement was a confrontation that a regime accustomed to leveraging silence found hard to discredit. Hungarians could unite 
Reynolds, David A.J. "Let the River Flow: Fighting a Dam in Communist Hungary." Hungarian Cultural Studies. eJournal of the American Hungarian Educators Association, Volume 13 (2020) DOI: 10.5195/ahea.2020.391

around the motto of the greatest Czech thinker, Comenius, omnia sponte fluant, absit violentia rebus: "everything flows willingly, without violence."

\section{Works Cited}

"A bős-nagymarosi vízlépcsőrendszer krónikája" ['Chronicle of the Bős-Nagymaros Barrage System]. 1989. In Tények Könyve Magyar és Nemzetközi Almanach 1990 [Book of Facts, Hungarian and International Almanach, 1990’]. Eds. György Baló and Iván Lipovecz. Debrecen: Ráció: https://www.arcanum.hu/hu/online-kiadvanyok/TenyekKonyve-tenyekkonyve-1/1990-7B2E/magyarorszag-A343/a-bos-A614/.

Blackwood, Algernon. 2019. The Willows. Weird Classics.

Borvendég, Zsuzsanna and Mária Palasik. 2016. "Untamed Seedlings: Hungary and Stalin's Plan for the Transformation of Nature." In In the Name of the Great Work: Stalin's Plan for the Transformation of Nature and Its Impact in Eastern Europe. Ed. Doubravka Olšáková. New York: Berghahn: 126-225.

Bozóki, András. "The Hungarian Democratic Opposition: Self-Reflection, Identity, and Political Discourse." Draft Paper:

https://politicalscience.ceu.edu/sites/politicalscience.ceu.hu/files/attachment/basicpage/50 /07-bozoki101.pdf.

“Charta 77 Document: 22/85.” 1985. September 13: http://www.csds.cz/cs/2166DS/version/17/part/15/data/Charta\%2077\%20Dokumenty\%201977-1989.pdf.

Csillag, Ádám. 1988. Dunaszaurusz ['Dunasaurus']. https://www.youtube.com/watch?v=bKFQssTZQRA

"Concerning the Gabčíkovo-Nagymaros Project: Annexes - Scientific Reports Volume 5 (Part 1)." 1994. International Court of Justice. May 2: https://www.icj-cij.org/files/caserelated/92/10935.pdf.

"Czechoslovakia-Hungary: Treaty Concerning the Construction and Operation of the Gabčíkovo-Nagymaros System of Locks and Hungarian Termination of Treaty.” 1993. International Legal Materials, 5: 1247-1290. http://www.jstor.org/stable/20693839.

D’Souza, Dilip. 2002. The Narmada Dammed: An Inquiry into the Politics of Development. London: Penguin.

Erskine, Brian. 1994. "Disaster on the Danube: A Hydroelectric Plant Wreaks Havoc." Harvard International Review, 2: 56-60.

Fermor, Patrick Leigh. 1986. Between the Woods and the Water. New York: New York Review of Books.

Fitzmaurice, John. 2018. Damming The Danube: Gabčíkovo and Post-Communist Politics In Europe. New York: Routledge.

Fradkin, Philip L. 1996. A River No More: The Colorado River and the West. Berkley: University of California Press.

Hamilton, Denise. 1989. "Danube 'Blues' Alter Politics for Hungarians." LA Times. August 13: http://www.latimes.com/la-fg-berlin-wall-archive-1989aug13-story.html.

Haraszti, Miklós. 1986. “Duna-dosszié” ['Danube Dossier’]. Beszélö [‘Speaker’]. 16: http://beszelo.c3.hu/cikkek/duna-dosszie. 
Reynolds, David A.J. "Let the River Flow: Fighting a Dam in Communist Hungary." Hungarian Cultural Studies. eJournal of the American Hungarian Educators Association, Volume 13 (2020) DOI: 10.5195/ahea.2020.391

Haraszti, Miklós. 1990. "The Beginnings of Civil Society: The Independent Peace Movement and the Danube Movement in Hungary." In In Search of Civil Society: Independent Peace Movements in the Soviet Bloc. Ed. Vladimir Tismaneanu. New York: Routledge: 71-87.

Harden, Blaine. 2012. A River Lost: The Life and Death of the Columbia. New York: Norton.

Hiltzik, Michael. 2010. Colossus: Hoover Dam and the Making of the American Century. New York: Free Press.

Hiltzik, Michael. 2010. “The False Promise of Hoover Dam.” LA Times. July 5: http://articles.latimes.com/2010/jul/05/opinion/la-oe-hiltzik-hoover-dam-20100705/2.

“In Memoriam Horváth Mihály.” 1988. Beszélő ['Speaker']. 25: http://beszelo.c3.hu/cikkek/inmemoriam-horvath-mihaly.

Irmanová, Eva. 2009. "Negotiations with Slovaks and the Struggle of the Czechoslovak and Hungarian Governments for Slovakia." In Czech and Hungarian Minority Policy in Central Europe, 1918-1938. Eds. Ferenc Eiler, Dagmar Hájková, et al. Prague: Institutional Research of the Academy of Sciences of the Czech Republic: 13-26.

Josephson, Paul. 2002. Industrialized Nature: Brute Force Technology and the Transformation of the Natural World. Washington: Island.

Josephson, Paul. 2016. "The East European Experience." In In the Name of the Great Work: Stalin's Plan for the Transformation of Nature and Its Impact on Eastern Europe. Ed. Doubravka Olšáková. New York: Berghahn: 1-41.

József, Atilla. 2013. "By the Danube.” Trans. Peter Zollman. In Inspired by Hungarian poetry: British Poets in Conversation with Attila József. Ed. Gyöngy Végh. London: Balassi Institute.

Kien, Péter [János Vargha]. 1984. "A Nagy Szlovák Csatorna” ['The Great Slovak Canal]. Beszélö ['Speaker']. 9: http://beszelo.c3.hu/cikkek/a-nagy-szlovak-csatorna.

Klein-Pejšová, Rebekah. 2015. Mapping Jewish Loyalties in Interwar Slovakia. Bloomington: Indiana UP.

Klein, Christine A. and Sandra B. Zellmer. 2014. Mississippi River Tragedies: A Century of Unnatural Disaster. New York: NYU Press.

Kürti, László. 2001. The Remote Borderland: Transylvania in the Hungarian Imagination. Albany: State University of New York Press.

Lauber, Volkmar. 1997. “Austria: A Latecomer which Became a Pioneer.” In European Environmental Policy: The Pioneers. Eds. Mikael Skou Andersen and Duncan Liefferink. Manchester: Manchester UP: 81-118.

Mauerhofer, Volker. 2016. "Wilderness Protection in Austria." In Wilderness Protection in Europe: The Role of International, European and National Law. Ed. Kees Bastmeijer. Cambridge: Cambridge UP: 247-268.

Munoz, Samuel E, et al. 2018. "Climatic Control of Mississippi River Flood Hazard Amplified by River Engineering." Nature. Volume 556 April 5: https://www.nature.com/articles/nature26145.

Nicolson, Harold. 2009. Peacemaking 1919. London: Faber and Faber.

Pope, Victoria. 1989. "A Dam on the Danube: The Greening of Hungarian Politics." The Alicia Patterson Foundation: http://aliciapatterson.org/stories/dam-danube-greening-hungarianpolitics. 
Reynolds, David A.J. "Let the River Flow: Fighting a Dam in Communist Hungary." Hungarian Cultural Studies. eJournal of the American Hungarian Educators Association, Volume 13 (2020) DOI: 10.5195/ahea.2020.391

Reynolds, David A.J. 2019. "Voyage of the Dammed." The Technoskeptic. Spring: 14-25.

Schwabach, Aaron. 1996. "Diverting the Danube: The Gabčíkovo-Nagymaros Dispute and International Freshwater Law.” Berkeley Journal of International Law. Volume 14, Issue 2: https://scholarship.law.berkeley.edu/cgi/viewcontent.cgi?article=1149\&context=bjil.

Scudder, Thayer. 2019. Large Dams: Long Term Impacts on Riverine Communities and Free Flowing Rivers. Singapore: Springer.

Thorpe, Nick. 2013. The Danube: A Journey Upriver from the Black Sea to the Black Forest. New Haven: Yale UP.

Thorpe, Nick. 2012. "Jaromír Š́bl talks to Nick Thorpe: The Main Victim is Nature." Hungarian Review, 2: http://hungarianreview.com/print/the_main_victim_is_nature.

Thorpe, Nick. 2012. "The Greening of the Danube: Restoring Oxbows in Austria and Germany." Hungarian Review, 3: http://hungarianreview.com/article/the_greening_of_the_danube.

Tökés, Rudolf. 1996. Hungary's Negotiated Revolution: Economic Reform, Social Change, and Political Succession. Cambridge: Cambridge UP.

Vargha, János. 2015. "The Enforcement of the Self-Interests of Nature Transformers." In The Spiritual Dimension of Business Ethics and Sustainability Management. Ed. László Zsolnai. Switzerland: Springer: 143-157.

Vargha, János. 1985. “Acceptance Speech - Janos Vargha / Duna Kör.” Right Livelihood Award. December 9: https://www.rightlivelihoodaward.org/speech/acceptance-speech-janosvargha-duna-kr/.

Vargha, János. 1981. "Egyre távolabb a jótól: Dokumentumok a Gabčíkovo-Nagymarosi vízlépcsőrendszer történetéből" [ 'Ever Farther from Good: Documents from the History of the Gabčíkovo-Nagymaros Barrage System’]. Valóság. 24: 1-23.

Vásárhelyi, Judit. 2014. "The Anatomy of the Slovak-Hungarian Underground Protection of the Danube in the Eighties." In Transboundary Symbiosis over the Danube: EU Integration between Slovakia and Hungary from a Local Border Perspective. Ed. Osamu Ieda. Sapporo: Slavic Research Centre: http://srch.slav.hokudai.ac.jp/coe21/publish/no27_ses/Chapter7.pdf.

Vásárhelyi, Judit. 1985. "Speech at the Right Livelihood Awards: An Emerging Environmental Movement." Making the History of 1989, Item \#316. December 9: http://chnm.gmu.edu/1989/archive/files/vasxheiyi---duna-kor_19f377538f.pdf.

Vida, Viktor. 2006. “A Duna Kör: A Duna Kör története a résztvevők emlékeiben” [The Danube Circle: The History of the Danube Circle in the Recollections of the Participants]. Thesis: Eötvös Loránd University.

Wandycz, Piotr S. 1962. France and Her Eastern Allies, 1919-1925: French-CzechoslovakPolish Relations from the Paris Peace Conference to Locarno. Minneapolis: University of Minnesota Press.

Zinke, Alexander. 2004. "The Hydropower Station Gabčíkovo: Deficits in Hydrology (Sediment Transport, Groundwater) and Biology." In Hydrology and Limnology-Another Boundary in the Danube River Basin: IAD International Workshop. Eds. J. Bloesch, D. Gutknecht, and V. Iordache:

http://hydrologie.org/BIB/Publ_UNESCO/TD_075_2005.pdf\#page=51. 
Reynolds, David A.J. "Let the River Flow: Fighting a Dam in Communist Hungary." Hungarian Cultural Studies. eJournal of the American Hungarian Educators Association, Volume 13 (2020) DOI: 10.5195/ahea.2020.391

Zloch-Christy, Iliana. 1988. Debt Problems of Eastern Europe. Cambridge: Cambridge UP. “1910. Évi Népszámlálás” ['1910 Census']. 1912. A Magyar Kir. Központi Statisztikai Hivatal. Budapest: Athenaeum.

“1988. Szeptember 12.” Állambiztonsági Szolgálatok Történeti Levéltára ['Historical Archives of the State Security Services']: https://www.abtl.hu/szolgaltatasok/nyiltter/virtualis_kiallitas/tuntetesek_1988/1988.09.12. 